\title{
Two Cases of Cerebral Infarction after Endoscopic Sinus Surgery
}

\author{
Ki Hun Jo, Yoon Soo Seo, Jae Hwan Kwon, and Joo Yeon Kim (iD \\ Department of Otolaryngology-Head and Neck Surgery, Kosin University College of Medicine, Busan, Korea
}

\section{부비동 내시경 수술 후 발생한 뇌경색 2예}

조기헌 · 서윤수 · 권재환 · 김주연

고신대학교 의과대학 이비인후과학교실

\author{
Received October 29, 2020 \\ Revised January 27, 2021 \\ Accepted February 1, 2021 \\ Address for correspondence \\ Joo Yeon Kim, MD, PhD \\ Department of Otolaryngology- \\ Head and Neck Surgery, \\ Kosin University \\ College of Medicine, \\ Kosin University Gospel Hospital, \\ 262 Gamcheon-ro, Seo-gu, \\ Busan 49267, Korea \\ Tel +82-51-990-6138 \\ Fax +82-51-245-8539 \\ E-mail oooo95@hanmail.net
}

Perioperative stroke is one of the most fatal complications for patients as well as for doctors. It is defined as a brain infarction or hemorrhage, occurring during or within 30 days after a surgical procedure. Most of the perioperative strokes have ischemic etiology while only $1 \%$ has hemorrhagic etiology, according to one study. The incidence of perioperative stroke is influenced by the complexity and type of the surgery. Generally, its incidence is very low, being about to $0.1-1.9 \%$, with majority of the cases pertaining to cardiac, vascular, neurological surgeries. Based on our research, most cases are perioperative strokes that occur after cardiac and vascular surgeries. Here we report two cases of cerebral infarction after endoscopic sinus surgery, which are very rare.

Korean J Otorhinolaryngol-Head Neck Surg 2021;64(7):505-10

Key Words Cerebral infarction - Endoscopic sinus surgery · Perioperative stroke.

\section{서 론}

수술관련뇌졸중(perioperative stroke)이란 수술 중이나 수술 후 발생한 뇌졸중을 뜻하고 대부분의 경우 허혈성이며, 그중에서도 색전증(embolism)이 원인이 되는 경우가 가장 많다. ${ }^{1,2)}$ 수술관련뇌졸중은 발생률이 낮지만, 수술 후 사망률 증가, 재원 기간의 증가, 장애 발생률 증가 등 심각한 결과를 초래하기 때문에 의사들이 가장 두려워하는 합병증 중 하나 이다. ${ }^{1,3}$

일반적인 외과수술에서의 수술관련뇌졸중의 발생률은 대 략 0.2 0.7\%로 매우 낮다. ${ }^{4)}$ 하지만 뇌졸중의 과거력이 있는 경우, 경동맥협착이 동반된 경우, 예정수술(elective surgery) 보다는 응급수술(urgent surgery)의 경우에 수술관련뇌졸중

This is an Open Access article distributed under the terms of the Creative Commons Attribution Non-Commercial License (https://creativecommons.org/licenses/by-nc/4.0) which permits unrestricted non-commercial use, distribution, and reproduction in any medium, provided the original work is properly cited.
의 발생률이 높은 것으로 알려져 있다. ${ }^{1,3)}$

저자가 조사한 바에 의하면 수술관련뇌졸중의 발생을 예 측하기 위한 여러 가지 모델들이 개발되어 왔으나, 대부분 심 장수술이나 혈관수술 시 뇌졸중 위험도를 예측하는 모델이 며 ${ }^{13)}$ 증례 보고 또한 심장이나 혈관수술 이후에 발생한 수술 관련뇌졸중에 대한 보고들이 주를 이루고 있다.

저자는 부비동 내시경수술 후 발생한 뇌경색 2예에 대하여 증례 보고와 함께 관련된 문헌을 고찰해 보고자 한다.

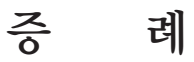

\section{증례 1}

47세 남자 환자가 약 1 개월 전부터 지속되는 양측 코막힘과 두통을 주소로 내원하였다. 환자의 body mass index(BMI) 는 $20.9 \mathrm{~kg} / \mathrm{m}^{2}$ 이었다. 흡연력과 음주력은 없었다. 환자는 천식 의 과거력이 있었으며 반복적인 기흥으로 흥막유착술을 받은 
병력이 있었다. 복용 중인 약물은 erdosteine $300 \mathrm{mg} \mathrm{BID(two}$ times a day), acebrophylline $100 \mathrm{mg}$ BID, prednisolone $5 \mathrm{mg}$ BID가 있었고, 흡입제로 fluticasone furoate/vilanterol(Relvar 100 Ellipta inhaler 100/25 $\mu \mathrm{g}$, GlaxoSmithKline, Ireland)과 tiotropium(Spiriva respimat)을 하루 1회씩 사용하고 있었다.

환자는 비내시경검사상 양측 중비도(middle meatus)의 폴 립이 관찰되었다. 안면부 컴퓨터단층촬영에서는 양측 비강과 부비동의 광범위한 연조직음영(soft tissue density)을 보였다 (Fig. 1). 상기 소견을 통해 양측 비강 폴립증을 진단하였고, 양측 부비동 내시경수술을 계획하였다. 이와 더불어 매부리 코와 양측 눈매 교정을 원해 비성형술과 양측 하안검 성형술 을 함께 시행하였다.

수술은 전신마취하에 진행되었다. 수술실 도착 후 활력 징
후는 혈압 145/90 mm Hg(평균 동맥압 $108 \mathrm{~mm} \mathrm{Hg}$ ), 심박수 80회/분, 호흡수 19 회/분, 체온 $36.5^{\circ} \mathrm{C}$, 산소포화도 $97 \%$ 였다. 마취 전 glycopyrrolate $0.2 \mathrm{mg}$, midazolam $3 \mathrm{mg}$ 을 투약하 였으며, 마취 유도를 위해 propofol $70 \mathrm{mg}$, remifentanil $70 \mu \mathrm{g}$ 을 정주하고, rocuronium $50 \mathrm{mg}$ 을 정주하여 근이완을 시킨 후 경구 기관 내 삽관을 시행하였다. 마취 시작 후 5 분째 심 박수 110회/분으로 esmolol $5 \mathrm{mg}$ 을 2회 정주하였다. 약물로 조절이 필요할 정도의 현저한 평균 동맥압 저하를 포함한 특 별한 사건 없이 수술을 마쳤고 estimated blood loss(EBL)은 $400 \mathrm{cc}$, 마취 시간은 260 분, 수술 시간은 220 분이었다.

수술 후 2 일째 양측 비강 패킹을 제거하였으며 따뜻한 식염 수로 하루 3회 비강 세척을 시행하였다. 이후 특이증상 없이 입원 중이던 환자는 수술 후 4일째부터 좌측 편마비와 좌측
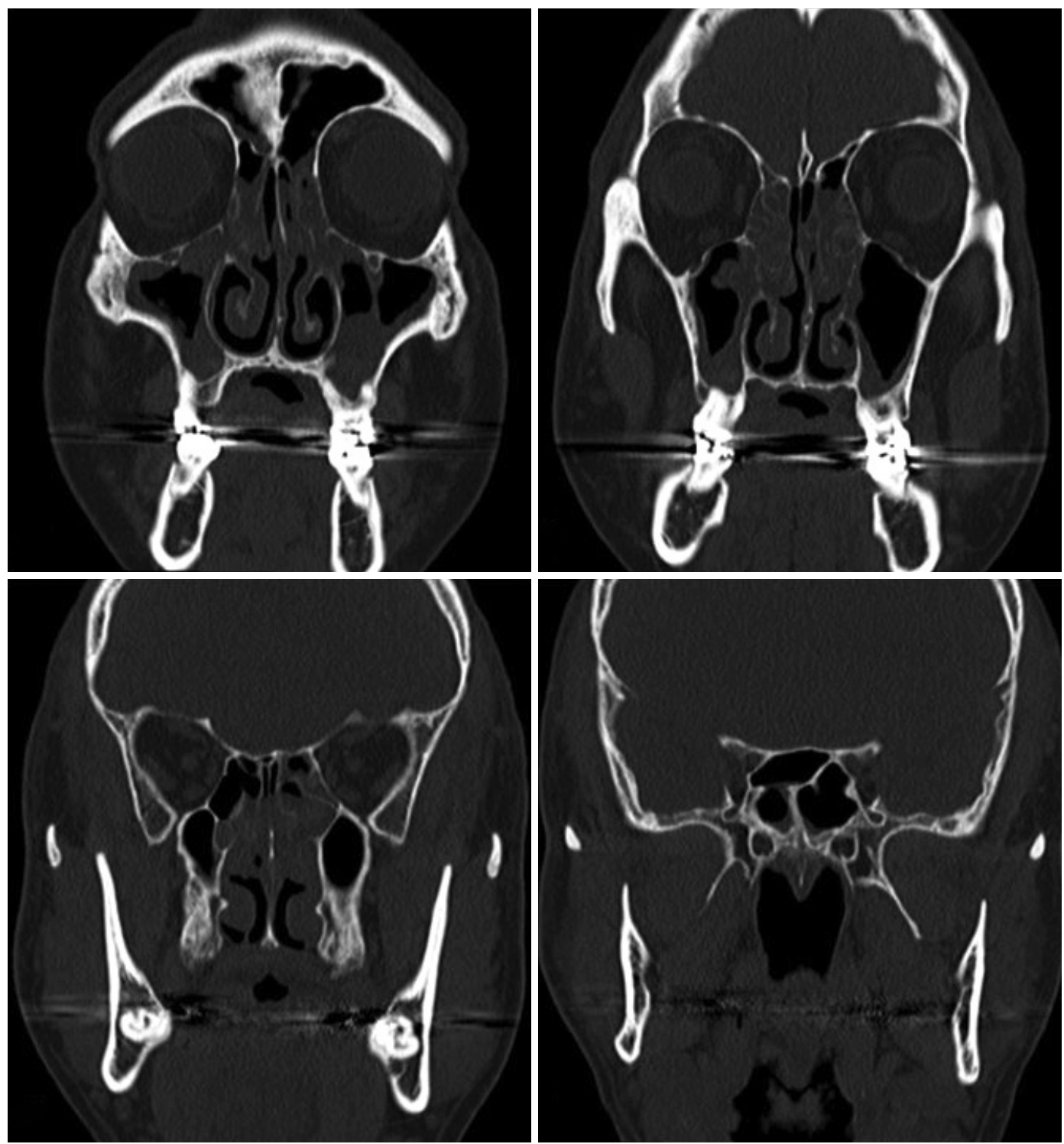

Fig. 1. Preoperative non-enhanced CT scan. It shows diffuse soft tissue density in both nasal cavity and paranasal sinuses at coronal view. 
상하지 감각저하를 호소하였고, 이에 뇌 자기공명영상 diffusion weighted image(DWI)와 fluid attenuated inversion recovery image 영상을 촬영하였다. MRI상 DWI에서 고신 호강도(high signal intensity)(Fig. 2A), apparent diffusion coefficient 영상에서 저신호강도(low signal intensity)(Fig. 2B)를 보이는 우측 기저핵(basal ganglia)과 대뇌부챗살(corona radiate)의 병변을 확인하였다. ${ }^{5}$

수술 후 발생한 급성 뇌경색(acute cerebral infarction) 진 단하에 즉시 신경과 협진 및 전과를 하였고, 환자는 뇌졸중 집중치료실로 전실되었다. 최근 수술한 병력으로 혈전용해제 (tissue plasminogen activator) 사용의 금기증에 해당하여 ${ }^{1)}$ 항혈소판제제의 부하용량을 투여하였고, 이후 aspirin $100 \mathrm{mg}$ QD(every day), clopidogrel $75 \mathrm{mg}$ QD, atorvastatin $80 \mathrm{mg}$ $\mathrm{QD}$ 를 경구 투여하였다.

수술 후 8일째부터 특별한 사건 없이 우측 비강 점막 전반 에 걸쳐 광범위한 비출혈이 종이컵 3컵 정도로 있어 Foley catheter를 사용한 후비공 패킹과 vaseline gauze를 사용한 심부 전비강 패킹을 시행하였다. 또한 금식, 총정맥영양법(total parenteral nutrition) 및 절대 침상 안정(absolute bed rest) 을 시행하였다. 이후로도 비강 전면의 거즈가 다 젖을 정도의 지속적인 비출혈이 있어 수술 후 9일째부터 clopidogrel을 중 단하였고, 수술 후 10 일째부터 비출혈이 조절되어 패킹을 제 거하였다. 이후 환자는 수술 후 13 일째까지 추가적인 비출혈 이 없어 퇴원하였다. 현재, 수술 후 4년째까지 특별한 후유증 없이 본원 이비인후과와 신경과 외래를 통해 경과관찰 중이 며 aspirin $100 \mathrm{mg} \mathrm{QD}$, atorvastatin $80 \mathrm{mg}$ QD를 경구 복용 중이다.

\section{증례 2}

64세 남자 환자가 약 1 개월 전부터 지속되는 양측 코막힘 을 주소로 본과 외래를 통해 내원하였다. 환자의 $\mathrm{BMI}$ 는 27.5 $\mathrm{kg} / \mathrm{m}^{2}$ 였다. 흡연력은 22갑년(0.5갑/일, 44년)이었으며 음주력 은 없었다. 환자는 고혈압, 심방세동, 경도인지장애의 병력이 있어 원활한 의사 소통이 다소 힘들었으며, 최근에 발생한 우 측 손목 부상으로 인해 운동 장애가 있었다. 복용 중인 약물 은 hydrochlorothiazide $12.5 \mathrm{mg} \mathrm{QD}$, losartan $50 \mathrm{mg} \mathrm{QD}$, bisoprolol $1.25 \mathrm{mg}$ QD, edoxaban $30 \mathrm{mg}$ QD, atorvastatin $10 \mathrm{mg}$ QD가 있었다.

비내시경검사 상 양측 중비도의 폴립이 관찰되었다. 안면부 컴퓨터단층촬영에서 우측 비중격만곡과 양측 비강과 부비동 의 광범위한 연조직 음영을 보였다(Fig. 3). 상기 소견을 통해 우측 비중격만곡과 양측 비강 폴립증(nasal polyposis)을 진 단하였고, 전신 상태가 좋지 않아 증상에 대한 약물적 치료를 우선적으로 권하였으나, 환자와 보호자가 적극 수술적 치료 를 원하시어 복용하고 있던 edoxaban(30 mg QD)을 3일간 중단하고, 비중격 교정술과 양측 부비동 내시경수술을 시행 하였다.

수술은 전신마취하에 진행되었다. 수술실 도착 후 활력 징 후는 혈압 120/80 mm Hg(평균 동맥압 $93 \mathrm{~mm} \mathrm{Hg}$ ), 심박수 92회/분, 호흡수 16 회/분, 체온 $36.6^{\circ} \mathrm{C}$, 산소포화도 $96 \%$ 였다. 마취 전 glycopyrrolate $0.2 \mathrm{mg}$ 을 투약하였으며, 마취 유도를 위해 propofol $90 \mathrm{mg}$, remifentanil $70 \mu \mathrm{g}$ 을 정주하고, rocuronium $50 \mathrm{mg}$ 을 정주하여 근이완을 시킨 후 경구 기관내 삽관을 시행하였다. 마취 시작 후 25분째 혈압 70/55 mm Hg (평균 동맥압 $60 \mathrm{~mm} \mathrm{Hg}$ )로 phenylephrine $50 \mu \mathrm{g}$ 을 투약하
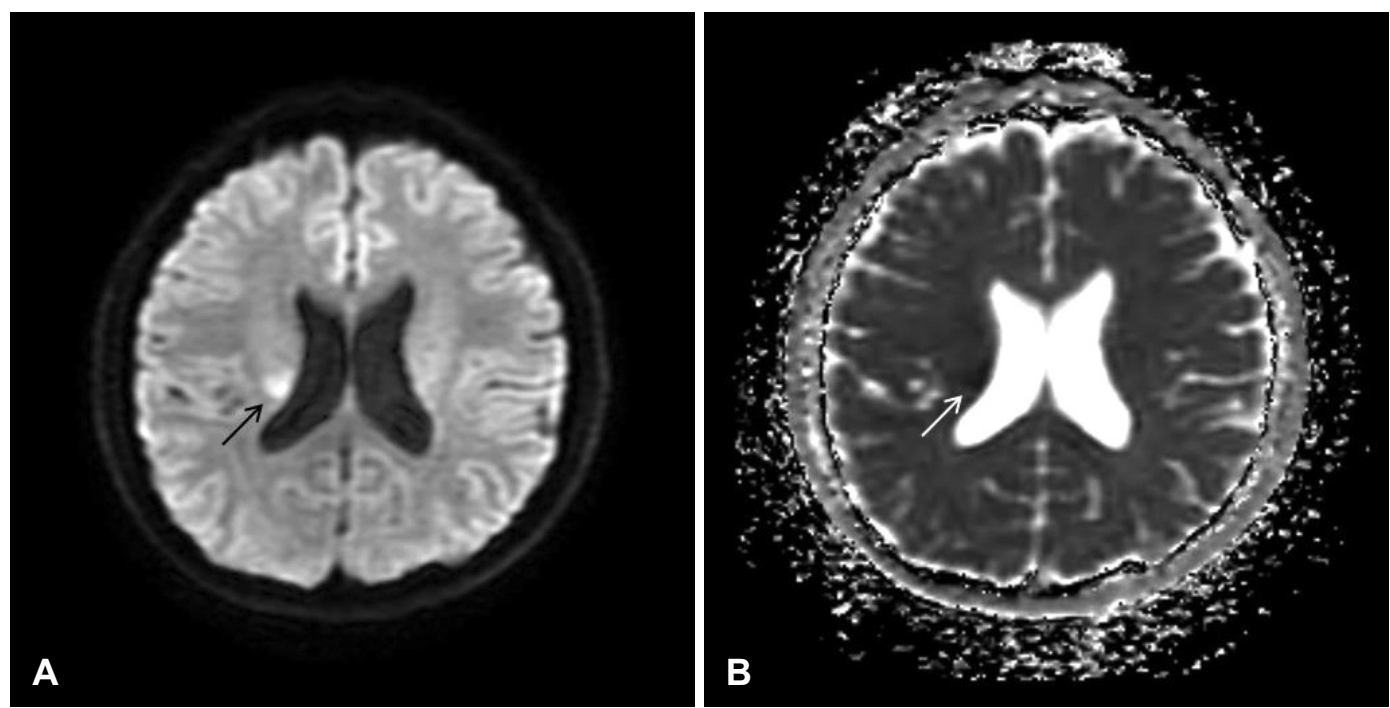

Fig. 2. Brain MRI DWI and fluid attenuated inversion recovery image image taken after neurologic symptoms occur. It shows high signal intensity lesion at the right basal ganglia and corona radiata in DWI (arrow, A), low signal intensity at the same area in apparent diffusion coefficient image (arrow, B). DWI: diffusion weighted image. 

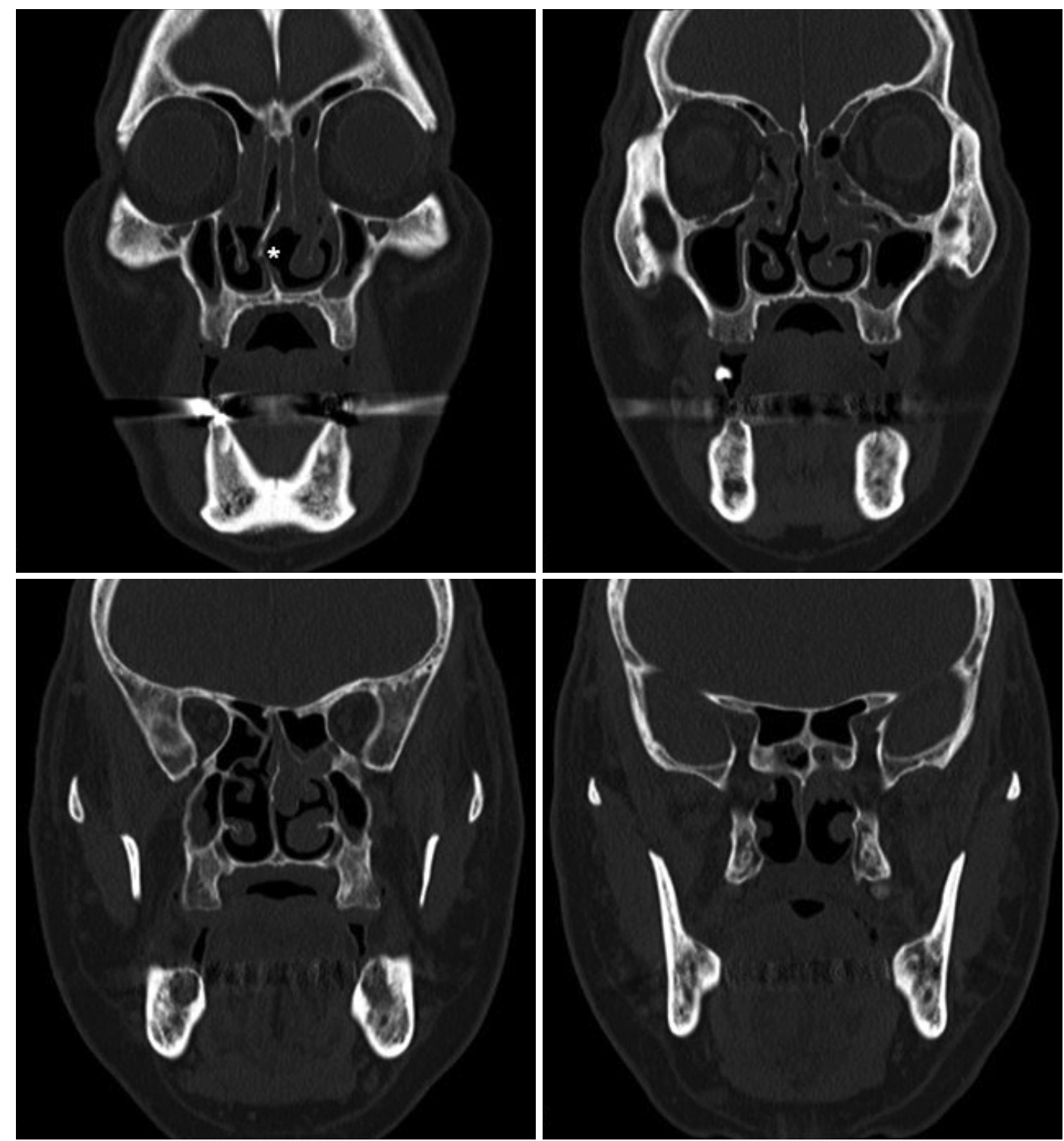

Fig. 3. Preoperative non-enhanced CT scan. It shows deviated nasal septum into right nasal cavity (asterisk) and diffuse soft tissue density in both nasal cavity and paranasal sinuses at coronal view.

였고, 수술 시작 후 30 분째 혈압 $54 / 33 \mathrm{~mm} \mathrm{Hg}$ (평균 동맥압 $40 \mathrm{~mm} \mathrm{Hg}$ )로 phenylephrine $250 \mu \mathrm{g}$, 수술 시작 후 45 분째 혈압 $67 / 32 \mathrm{~mm} \mathrm{Hg}$ (평균 동맥압 $44 \mathrm{~mm} \mathrm{Hg}$ )로 phenylephrine $150 \mu \mathrm{g}$ 을 투약하였다. 다른 특별한 사건 없이 수술을 마 쳤고 $\mathrm{EBL}$ 은 $50 \mathrm{cc}$, 마취 시간은 190 분, 수술 시간은 140 분 이었다.

수술 후 병동에서 회복 중(수술 후 90분) 환자는 초조한 증 세(agitation)를 보였으나 신경학적 검사상 특이 소견은 없었 다. 이에 수술 후 발생한 섬망(postoperative delirium)으로 생각하고 정신건강의학과에 의뢰하여 quetiapine $25 \mathrm{mg} \mathrm{QD}$ 를 경구 투여하였다. 수술 330 분 후 환자는 초조한 증세가 심 해지며 중등도의 완전언어상실증(global aphasia)이 동반되
어, 즉시 뇌 및 경동맥의 MRI와 magnetic resonance angiography(MRA)를 촬영하였고, 환자는 MRI 촬영 대기 중 우 측 상하지 근력저하와 감각저하를 호소하였다. MRI상 DWI 에서 고신호강도를 보이는 좌측 후두엽의 병변(Fig. $4 \mathrm{~A}$ )과 좌측 전두엽의 다발성 병변(Fig. 4B)을 확인할 수 있었다. ${ }^{5}$ 또 한 경동맥 MRA상 좌측 내경동맥이 조영되지 않는 것을 확 인하였다(Fig. 4C). ${ }^{6}$

수술 후 발생한 급성 뇌경색 진단하에 즉시 신경과 및 신경 외과와 협진하여 응급으로 동맥 내 혈전제거술(intra-arterial thrombectomy)을 시행하였다. 이후 환자는 신경과로 전 과 및 뇌졸중집중치료실로 전실되었다. 이어서 항혈소판제제 의 부하용량을 투여한 후 aspirin $100 \mathrm{mg}$ QD, clopidogrel 

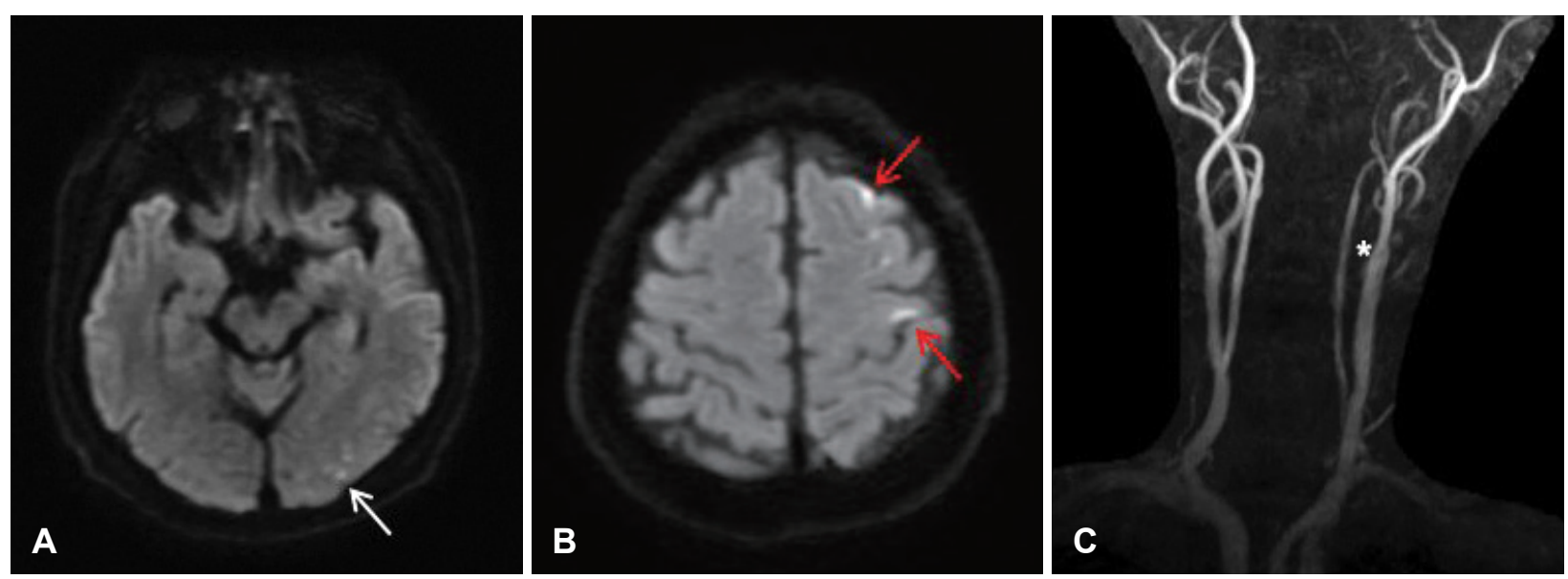

Fig. 4. Brain MRI DWI and carotid MRA image taken after neurologic symptoms occur. It shows high signal intensity lesion at the left occipital lobe (arrow, A) and multifocal high signal intensity lesions at the left frontal lobe (arrows, B) in DWI. Carotid MRA shows total occlusion of the left internal carotid artery (asterisk, C). DWl: diffusion weighted image, MRA: magnetic resonance angiography.

$75 \mathrm{mg}$ QD, atorvastatin $80 \mathrm{mg} \mathrm{QD}$ 를 경구 투여하였다.

수술 후 1 일 째 비출혈 및 후비루 소견이 없고 비강 전면의 거즈도 젖지 않아 양측 비강 패킹을 제거하였고, 수술 후 5일 째 비중격에 고정되었던 실라스틱판(silastic sheet)도 제거하 였다. 이후 수술로 인한 특별한 비과적 합병증은 없었다.

환자는 13일간 뇌졸중집중치료실에서 치료받았다. 초조한 증세는 호전되었으나, 다른 신경학적 증상은 호전이 없었다. 이후 환자 및 보호자가 원하여 적극적인 재활 치료를 위해 타 병원으로 전원되었다.

\section{고 찰}

수술관련뇌졸중은 수술 중이나 수술 후 발생한 뇌졸중을 의미하고, 일반적으로 수술 후 30 일 내에 허혈 또는 출혈로 인해 발생한 뇌졸중으로 정의한다. ${ }^{2}$

심장수술, 혈관수술과 신경외과적 수술 등을 제외한 일반 적인 외과수술의 경우, 수술관련뇌졸중의 발생률은 대략 $0.2 \sim 0.7 \%$ 로 매우 낮지만 뇌졸중의 과거력이 있는 경우 $2.9 \%$, 경동맥협착이 동반되거나 수술 전 뇌혈류감소로 인한 증상이 있는 경우 $3.6 \%$ 로 비교적 높다. ${ }^{24)}$ 특히 경동맥내막절제술의 경우 최대 $6.6 \%$, 심장수술의 경우 최대 $15.6 \%$ 까지 발생률이 올라간다. ${ }^{4}$

수술관련뇌졸중의 위험 요인들로는 크게 환자 요인과 수술 요인으로 나누어 볼 수 있다.) 환자 요인으로는 고령, 성별(여 성), 뇌졸중의 과거력, 고혈압, 당뇨병, 신부전, 흡연, 만성폐쇄 성폐질환, 말초혈관질환, 심장질환 등의 과거력이 있다.,3) 수 술 요인은 다시 수술 중 요인과 수술 후 요인으로 나누어 볼 수 있다. 수술 중 요인으로는 수술 유형 및 특성, 마취의 종류, 수술 시간, 죽상경화 변화를 가진 근위부 대동맥의 수기조작,
부정맥, 고혈당, 혈압 변화 등이 있고, 수술 후 요인으로는 심 부전, 심근경색, 부정맥, 고혈당, 그리고 탈수 및 혈액 소실 등 이 있다. ${ }^{1,3}$ 첫 번째 증례의 경우 비교적 긴 수술 시간과 수술 중 발생한 다량의 혈액 소실이 수술관련뇌졸중 발생에 영향 을 미쳤을 수 있다. 다행히 첫 번째 증례에서는, 수술 중 약물 로 처치가 필요할 정도의 극심한 혈압 변화는 일어나지 않았 다. 일반적으로 전신마취는 국소마취에 비해 수술 관련 합병 증이 발생할 가능성이 높다고 알려져 있다. ${ }^{3)}$ 두 증례 모두에 서 전신마취하 수술이 진행되어 수술관련뇌졸중이 발생할 가능성을 높였을 수 있다. 두 번째 증례의 경우 수술관련뇌 졸중 발생에 관한 환자 요인으로 고혈압 병력, 심방세동 병력, 흡연력을 들 수 있으며 수술 전 복용 중이던 항응고제(edox$\mathrm{aban)}$ 를 3일간 중단한 것 또한 영향을 미쳤을 수 있다. 더불 어, 수술 전 확인되지 않았지만 좌측 경동맥의 죽상경화증도 수술관련뇌졸중의 발생 가능성을 높였을 수 있다. 심장 초음 파 검사상 좌심실 구혈률(ejection fraction, $\mathrm{EF}$ )이 $40 \%$ 미 만인 경우 수술관련뇌졸중 발생의 위험인자로 작용할 수 있 다고 알려져 있으남 두 번째 증례의 환자에서 술전 시행한 심장 초음파 검사상 $\mathrm{EF}$ 는 $65.23 \%$ 였다. 두 번째 증례에서 수 술 중 요인으로는 긴 수술 시간과 수술 중 혈압 변화를 들 수 있겠다.

수술관련뇌졸중에 대한 증례 보고 및 예측을 위한 여러 가 지 모델들이 개발되어 왔으나 대부분 심장수술 및 혈관수술 에 국한되어 있다.13) 이비인후과 영역에서 수술관련뇌졸중은 1993년 Nosan 등ㄱㅇㅣ 수술 후 발생한 뇌졸중 5예를 발표하였 으나 5명의 환자 모두 두경부수술을 받았다. Cramer 등은 두경부수술을 받은 환자들 중 경부절제술을 함께 받은 환자 군에서 경부절제술을 받지 않은 환자군보다 수술관련뇌졸중 의 발생률이 높았다고 보고한 바가 있다. 
수술관련뇌졸중의 발생률을 최소화하기 위해서는 환자의 위험 요인에 따라 수술 시기, 수술 방법, 수술 시간, 수술 전 항응고제나 항혈전제의 조절 등을 고려할 필요가 있다. 특히 고령이거나 관상동맥질환, 말초혈관질환, 고혈압, 당뇨병, 뇌 졸중의 병력이 있거나 흡연력이 있는 고위험 환자들은 수술 전 경동맥 초음파를 통해 경동맥협착 유무를 확인하는 것이 바람직하다. ${ }^{9)}$ 두 번째 환자의 경우 고혈압, 심방세동, 흡연력 등의 위험 인자가 있었으므로 수술 전 경동맥협착의 유무를 평가하는 것이 수술관련뇌졸중 발생 예측에 도움이 되었을 수 있다. 그리고 응급수술이 아닌 예정수술의 경우에는 뇌졸 중 발생 9개월 이후로 미루는 것이 바람직하다. ${ }^{10)}$ 수술 전 항 응고제나 항혈전제의 조절 또한 수술관련뇌졸중과 수술관련 출혈에 대한 득실을 고려하여 기간을 정해야 한다. 수술 중 평균 동맥압이 $65 \mathrm{~mm} \mathrm{Hg}$ 아래로 10분 이상 내려가거나, 기 저치로부터 $30 \%$ 이상 감소할 때 수술관련뇌졸중의 위험이 증가한다는 보고가 있으므로 수술 중 평균 동맥압의 유지가 수술관련뇌졸중의 예방에 도움을 줄 수 있다. ${ }^{9}$ 두 번째 환자 의 경우 혈관수축제의 사용에도 평균 동맥압이 $65 \mathrm{~mm} \mathrm{Hg}$ 이하로 10 분 이상 내려갔을 뿐만 아니라, 기저치로부터 $30 \%$ 이상 감소하여 수술관련뇌졸중 발생에 영향을 미쳤을 수 있 다. 따라서 수술 중 평균 동맥압 감소에 대해 적극적으로 조 절하는 자세가 필요하다.

이러한 노력에도 불구하고 수술관련뇌졸중이 발생하면 신 속한 신경과와 신경외과 협진이 이루어지는 것이 바람직하다. 본 증례에서 두 사례 모두 수술 후 병동에서 회복 중 호소한 증상에 대해 빠르게 진단하고 대처하였다. 하지만 고위험군 증례의 경우는 예후가 좋지 않았다.

본 증례는 부비동 내시경수술 후 발생한 급성 허혈성 뇌졸 중에서 신경학적인 증상 발생 후 뇌 MRI 촬영을 통한 진단과 경구 항혈소판제 및 응급 동맥 내 혈전제거술을 통한 치료에 대한 경험을 보고한 증례이다. 수술관련뇌졸중의 위험을 최 소화하기 위해서는 심혈관 수술뿐만 아니라 모든 수술에서 수술 전 세심한 환자 평가와 수술 중 혈압 조절, 그리고 수술
후 환자가 호소하는 증상에 대한 적절하고 신속한 처치가 중 요할 것이다. 술자 또한 고위험군 환자의 경우 수술 전 항응 고제 또는 항혈전제를 유지하거나 국소마취하에 수술하는 것 을 고려해볼 수 있겠고, 수술 시간 감소 및 혈액 소실의 최소 화를 위해 노력을 기울여야 하겠다.

\section{Acknowledgments}

None.

\section{Author Contribution}

Conceptualization: Jae Hwan Kwon, Joo Yeon Kim. Data curation: Ki Hun Jo, Yoon Soo Seo. Formal analysis: Jae Hwan Kwon, Joo Yeon Kim. Methodology: Joo Yeon Kim. Supervision: Jae Hwan Kwon, Joo Yeon Kim. Writing_original draft: Ki Hun Jo. Writing — review \& editing: Joo Yeon Kim.

\section{ORCID}

Joo Yeon Kim https://orcid.org/0000-0001-8432-6056

\section{REFERENCES}

1) 대한뇌졸중학회. 뇌졸중. 2nd ed. 서울: 범문에듀케이션;2015. p.291-8.

2) Ko SB. Perioperative stroke: Pathophysiology and management. Korean J Anesthesiol 2018;71(1):3-11.

3) Selim M. Perioperative stroke. N Engl J Med 2007;356(7):706-13.

4) Brooks DC, Schindler JL. Perioperative stroke: Risk assessment, prevention and treatment. Curr Treat Options Cardiovasc Med 2014;16(2):282.

5) Finelli PF. Diagnostic approach to restricted-diffusion patterns on MR imaging. Neurol Clin Pract 2012;2(4):287-93.

6) Thurnher SA. MRA of the carotid arteries. Eur Radiol 2005;15 Suppl 5:E11-6.

7) Nosan DK, Gomez CR, Maves MD. Perioperative stroke in patients undergoing head and neck surgery. Ann Otol Rhinol Laryngol 1993;102(9):717-23.

8) Cramer JD, Patel UA, Maas MB, Samant S, Smith SS. Is neck dissection associated with an increased risk of postoperative stroke? Otolaryngol Head Neck Surg 2017;157(2):226-32.

9) Jayaraman DK, Mehla S, Joshi S, Rajasekaran D, Goddeau RP Jr. Update in the evaluation and management of perioperative stroke. Curr Treat Options Cardiovasc Med 2019;21(11):76.

10) Jørgensen ME, Torp-Pedersen C, Gislason GH, Jensen PF, Berger $\mathrm{SM}$, Christiansen $\mathrm{CB}$, et al. Time elapsed after ischemic stroke and risk of adverse cardiovascular events and mortality following elective noncardiac surgery. JAMA 2014;312(3):269-77. 